\title{
INFLUENCE OF THE ENTREPRENEUR AND ENTERPRISE CHARACTERISTICS ON SUCCESS OF CAGE FISH FARMING IN THE ASUOGYAMAN AND SOUTH DAYI DISTRICTS, GHANA
}

\author{
Anaglo J. N. ${ }^{1}$--- Freeman C. K. ${ }^{2}$--- Kumah W. K. ${ }^{3}$--- Boateng S. D. ${ }^{4}$--- Manteaw S. A. ${ }^{5}$ \\ 1,9,3.4 Department of Agricultural Extension, University of Ghana, Legon, Accra, Ghana \\ ${ }^{5}$ Council for Scientific and Industrial Research, Accra, Ghana
}

\begin{abstract}
Aquaculture is becoming a very important source of income to many people as well as a source of protein in their diets. This study examined the influence of the entrepreneur and enterprise characteristics on smallscale cage fish enterprises in the Asuogyaman and South Dayi Districts. The research employed a descriptive-correlation survey design, which used quantitative method to collect data from 105 owners and managers of small-scale cage fish enterprises. The findings revealed that age of entrepreneurs influenced customer satisfaction as entrepreneurs experience also influenced growth in sales. It was observed that technical know-how, attitude towards work, and managerial skills, had a significant relationship with profitability, and customer satisfaction. Finally, age of the enterprise was found to have a significant relationship with growth in sales. In conclusion, all the variables had positive relationships with enterprise success, but not all the relationships were significant. It is recommended that cage fish farmers should be encouraged to invest more in technical education, which will help improve on the success of their enterprises. Furthermore, farmers should take precautions to reduce the risk of failure to increase their chances of success and survival.
\end{abstract}

Keywords: Cage fish farming, Entrepreneur, Aquaculture, Customer satisfaction, Enterprise success, Technical knowhow, Managerial skills, Profitability.

Received: 9 July 2014/ Revised: 20 August 2014/ Accepted: 12 August 2014/ Published: 18 August 2014

\section{Contribution/ Originality}

The study contributes to existing literature to emphasize the relevance of human resource development in the areas of technical education and entrepreneurs' attitude towards work to the success of cage fish farming. Therefore investment in human resource of entrepreneurs is necessary for the success of cage fish farmers' enterprises.

\section{BACKGROUND OF THE STUDY}

Aquaculture is the farming of aquatic organisms such as fish, molluscs, crustaceans, aquatic plants, crocodiles, alligators, turtles, and amphibians while cage fish farming involves the planned 
growth and cultivation of fish in cages on water bodies (FAO, 2012). Aquaculture remains one of the fastest-growing animal food-producing sectors. Hopefully, in the next decade, total production from both capture and aquaculture will exceed that of beef, pork or poultry. In SubSaharan Africa fish consumption levels remain so low and the people are failing to benefit from the contributions that fisheries and aquaculture are increasingly making elsewhere in terms of sustainable food security and income (FAO, 2012). Capture fisheries together with aquaculture supplied the world with about 148 million tonnes of fish in 2010 (with a total value of US\$217.5 billion), of which about 128 million tonnes was utilised as food for people. Of the 126 million tonnes of fish available for human consumption in 2009, fish consumption was lowest in Africa (9.1 million tonnes). From the year 2005 to 2011 , Ghana was able to produce only an average of $58 \%$ of the total annual fish requirement (MOFA, 2012). This clearly shows that the country faces a huge fish supply deficit that has to be filled. This gap can be filled if the country harnesses her fresh water resources effectively through encouraging and supporting cage fish farming.

Protein malnutrition is a concern in many developing countries including Ghana. Malnutrition affects all age groups and it is usually common among the poor and those with very scanty information on access to health education, clean water and good sanitation. In a study by FAO (2012), it was discovered that protein-energy malnutrition (PEM), is the most lethal form of malnutrition globally. In Ghana, the situation is not different. It has been observed that the most prevalent form of malnutrition is PEM, which causes growth retardation and underweight (GHS, 2005). About $54 \%$ of all deaths beyond early infancy were associated with PEM, making this the single greatest cause of child mortality in Ghana (GHS, 2005). Fish is an important source of animal protein in Ghana. Increased availability of fish can therefore reduce protein malnutrition in the country. According to Ofori (2000), Ghana has the potential to increase fish production and availability through aquaculture and improved fisheries management. Apart from its potential to contribute towards attaining food security, cage fish farming offers poverty alleviation through job creation. It has less harmful impact on the ecosystem as compared to the use of harmful and destructive fish farming methods like the use of explosives and pesticides by some fisher folk to catch fish from the wild.

In spite of the benefits derived from cage fish farming, the industry faces a number of challenges. These include high cost and poor quality of fingerlings and feed, inadequate funds, poor technical know-how and inadequate extension services. Frimpong et al. (2011) identified lack of capital and extension as the main challenges facing adopters of cage fish culture in Ghana. These challenges need to be addressed in order to attain success and sustainability in the cage fish industry.

\section{AQUACULTURE AND FISH PRODUCTION IN GHANA}

Aquaculture was believed to have started in the northern part of Ghana when the first fish ponds were built in 1953 by the former Department of Fisheries (Hiheglo, 2008). These fish 
ponds served as hatcheries which supported the culture-based reservoir fishery development program. Farmers living in nearby communities were taught fishing skills which were not traditionally used for fishing. This project was not successful because of poor site selection, ponds not drained and farmers without any focus (Hiheglo, 2008). However, some farmers in the country started developing interest in fish farming and in the late 1990s, Tropo Farms and Crystal Lake Fish Ltd., among others, established cage fish farms on the Volta Lake. Later, over 60 cage aquaculture enterprises were established between 2000 and 2010 (Anane-Taabeah, 2012).

Aquaculture is basically carried out in ponds and cages. The main fishes cultivated are Tilapia (Oreochromisniloticus) Catfish (Clariasgariepinus) and heterotis niloticus. Tilapia comprises of over $80 \%$ of the fish population (Hiheglo, 2008)

The fisheries sector employs $10 \%$ of the total population from both urban and rural areas and contributes about 3\% of the total GDP and 5\% of GDP in agriculture (FAO, 2011). Opportunities for value addition such as fish processing (frying, salting and smoking), exist and women form the key players in this industry.

The annual fish requirement for the country is 880,000 metric tonnes, but only 400,000 metric tonnes are produced creating a deficit of 480,000 metric tonnes. According to Simpson (2012), this deficit is due to the fact that fish farming is done mainly at subsistence level with a few commercial farms operating in the country. Even though fish production from non-capture sources appear to be on the rise in recent years, it still constituted less than $3 \%$ of Ghana's total fish supply between 2009 and 2011 (MOFA, 2013).

\section{STATEMENT OF THE PROBLEM}

In the past decade, there had been a rush by individuals and organisations to establish cage fish farms on the Volta Lake in the Asuogyaman and South Dayi Districts, mainly due to the benefits to be derived from such an enterprise. However, in spite of the large investments made, some of these enterprises failed and folded up after a few months of operation. These problems might have arisen due to demographic characteristics and competence of the entrepreneurs and also enterprise characteristics of cage fish farms, among others.

Demographic characteristics of entrepreneurs have been identified as factors that influence the performance and success of enterprises (Rutherford and Oswald, 2000; Man et al., 2002). For example, even though two different studies have shown that the manager's level of education is a significant determinant of the growth of enterprises, the strengths of the relationships were not statistically significant, suggesting that the level of education did not actually matter in explaining the growth of small scale enterprises (McPherson, 1996); (Unger et al., 2011). However, other authors have identified education and training as contributors to the growth and success of small enterprises (Simpson et al., 2004; Kolstad and Wiig, 2013).

It is believed that competence of the entrepreneur can also contribute to the success of cage fish farming. This has been observed by some authors who have indicated that competence of the 
entrepreneur is crucial to the success of the enterprise (Verhees and Meulenberg, 2004; Ahmad et al., 2011). Some of these competences are innovativeness of the entrepreneur, positive attitudes towards work, technical know-how and training experience. Such competences may initially lead to competitive advantage of the enterprises which finally leads to enterprise growth.

There is empirical evidence that success of small businesses depends on the characteristics of the enterprise and the characteristics of the environment within which the enterprise operates (Rutherford and Oswald, 2000).While Bigsten and Gebreeyesus (2007) found the existence of systematic relationships between firm growth and firm attributes, (McMahon, 2001) also theorised that enterprise size was significantly linked to better business performance as larger enterprises were found to have higher levels of success.

So far, there is no empirical evidence on factors responsible for failure or success of cage fish farming in Ghana and this has necessitated this research to unearth the factors responsible for the folding up of some of these farms and why some are successfully operating. A major question that arises is "what are the contributing factors to success or failure of cage fish farming in the Asuogyaman and South Dayi districts? To address this question, a research objective is set as follows:

"To examine factors responsible for failure or success of cage fish farming in the Asuogyaman and South Dayi Districts". Specifically, the study had the following objectives:

i. To examine the relationship between demographic characteristics of entrepreneurs and success of cage fish farming.

ii. To examine the relationship between competencies of entrepreneurs and success of cage fish farming.

iii. To examine the relationship between enterprise characteristics and success of cage fish farming.

\section{METHODOLOGY}

The descriptive-correlation survey research design was used for this study because the design helped to establish relationships between the variables. Creswell (2004) defined correlation as a statistical test to establish relationships between two or more variables. Quantitative data were collected using close-ended and open-ended questions during the survey.

The target population for this study was made up of entrepreneurs of all the 114 small scale cage fish enterprises in the Asuogyaman and South Dayi Districts. According to data available at the Ministry of Food and Agriculture (MOFA), the Asuogyaman and South Dayi Districts currently have 69 and 45 small-scale cage fish enterprises respectively dotted along the banks of the Volta Lake (G. Afetorgbor, personal communication, March 2013).

In order to increase precision (Creswell, 2004), all the cage fish farmers were considered for the study. However, sixty-two (62) managers of small scale cage fish enterprises were interviewed in the Asuogyaman District, while 43 managers were also interviewed in the South Dayi District, 
making a total of 105. The number reduced because some of the managers lived outside these two districts and could not be reached during the study.

Data were compiled, sorted, edited and coded to ensure the required quality, accuracy and completeness. It was entered into the computer using the Statistical Package for Social Sciences (SPSS) for analysis.

\subsection{Measuring the Variables}

Profitability, growth in sales, growth in size of enterprise and growth in number of employees were calculated from numeric data collected from respondents covering the number of years that their respective enterprises had been in operation. A five point Likert scale ranging from $1=$ strongly disagree, $2=$ disagree, $3=$ not sure, $4=$ agree and $5=$ strongly agree was adopted to measure customer satisfaction. This is because Likert scales do not restrict the respondents to yes or no answers, but have the advantage of allowing for degrees of opinion, and even no opinion at all (McLeod, 2008). The demographic characteristics (age, education and experience on the job) were measured using open and close ended questions. The competencies of cage fish entrepreneurs (technical know-how, attitude, and managerial skills) were also measured using five point Likert scales ranging from $1=$ strongly disagree, $2=$ disagree, $3=$ not sure, $4=$ agree, and $5=$ strongly agree. This was in view of the fact that Michalos et al. (2011) also used the Likert scale to measure knowledge, attitude and behaviour of students. Age as an enterprise characteristic was determined using open and close ended questions.

\section{RESULTS AND DISCUSSIONS}

\subsection{Relationship between Demographic Characteristics and Enterprise Success}

The demographic characteristics considered in this analysis were age of respondents, highest level of education and the number of years served as a manager of the cage fish enterprise. Success of the cage fish enterprises was measured by profitability, growth in sales, growth in size of enterprise, increase in number of employees, and customer satisfaction.

\subsubsection{Age of Respondents and Enterprise Success}

Most respondents $(83.8 \%)$ were observed to be above 40 years. The findings from the correlation analysis between customer satisfaction and the age of entrepreneurs showed a correlation coefficient of 0.279 (Table 1). This was a weak but positive relationship $(r=0.279, p=$ $0.004<0.05)$, and implied that the more the cage fish farmers or entrepreneurs got older, the more their customers become satisfied with their goods and services. This finding is at variance with that of Sinha (1996), who said that successful entrepreneurs were comparatively younger in terms of age. It also contradicts findings by Reynolds et al. (2000) that younger entrepreneurs have a higher growth ambition, which also drives success. Other enterprise success factors such as profitability, growth in sales and growth in size of enterprise recorded positive but insignificant 
correlation with the ages of respondents. Also, growth in number of employees as an enterprise success indicator displayed a positive insignificant relationship with age of the entrepreneur.

Table-1. Relationship between Demographic Characteristics and Enterprise Success

\begin{tabular}{|c|c|c|c|c|}
\hline Variables & Test of significance & $\begin{array}{ll}\text { Age } & \text { of } \\
\text { entrepreneur }\end{array}$ & Education & Experience \\
\hline \multirow{3}{*}{ Profitability } & Pearson Correlation & 0.009 & 0.166 & 0.163 \\
\hline & Sig. (2-tailed) & 0.925 & 0.090 & 0.096 \\
\hline & $\mathrm{N}$ & 105 & 105 & 105 \\
\hline \multirow{3}{*}{ Growth in Sales } & Pearson Correlation & 0.158 & 0.098 & $0.189^{*}$ \\
\hline & Sig. (2-tailed) & 0.108 & 0.322 & 0.040 \\
\hline & $\mathrm{N}$ & 105 & 105 & 105 \\
\hline \multirow{4}{*}{$\begin{array}{l}\text { Growth in size of } \\
\text { enterprise }\end{array}$} & Pearson Correlation & 0.075 & 0.008 & 0.120 \\
\hline & Sig. (2-tailed) & 0.449 & 0.934 & 0.224 \\
\hline & $\mathrm{N}$ & 105 & 105 & 105 \\
\hline & Pearson Correlation & 0.188 & 0.153 & 0.056 \\
\hline \multirow{2}{*}{$\begin{array}{l}\text { Growth in number of } \\
\text { employees }\end{array}$} & Sig. (2-tailed) & 0.055 & 0.120 & 0.570 \\
\hline & $\mathrm{N}$ & 104 & 104 & 104 \\
\hline \multirow[b]{3}{*}{ Customer Satisfaction } & Pearson Correlation & $0.279^{*}$ & 0.044 & 0.084 \\
\hline & Sig. (2-tailed) & 0.004 & 0.652 & 0.393 \\
\hline & $\mathrm{N}$ & 105 & 105 & 105 \\
\hline
\end{tabular}

*. Correlation is significant at the 0.05 level (2-tailed).

\subsubsection{Educational Level of Respondents and Enterprise Success}

It was observed that respondents with secondary/technical school education were in the majority (45.7\%) followed by those with basic education (38.1\%), tertiary education $(11.4 \%)$ and no formal education $(4.8 \%)$. The educational levels of the cage fish farmers had positive but insignificant relationship with various factors of enterprise success (Table 1) as the $p$-values for profitability, growth in sales, growth in size of enterprise, growth in number of employees and customer satisfaction were $0.090,0.322,0.934,0.120$ and 0.652 respectively $(p>0.05)$. The study therefore shows that a higher educational level of cage fish farmers will not necessarily result in higher enterprise success. There are mixed results concerning this finding. For example, Hall (2000) observed that managers of Small and Medium Scale Enterprises (SMEs) who are highly educated achieved lower growth rates than those not well educated even though Islam et al. (2011) indicated that persons with higher educational levels were more successful in their businesses. However, Thapa et al. (2008) also observed that the level of education of entrepreneurs had moderate positive relationship with profit from the business.

\subsubsection{Experience of Enterprise Managers and Enterprise Success}

The number of years a person works in an enterprise is an important factor in determining his enterprise success. Enterprise managers who had been in the business for more than three years formed $41.9 \%$, those below two years were $21.9 \%$ and those above four years formed $36.2 \%$ 
of the total respondents. Correlation results showed a significant positive relationship between number of years the entrepreneurs have been in the enterprise and growth in sales $(\mathrm{r}=0.189, \mathrm{p}=$ $0.04<0.05)($ Table 1). Lee and Denslow (2005) also identified a positive relationship between the number of years of experience on the job and enterprise success. Similarly, Woldie et al. (2008) indicated that firm growth is positively influenced by previous experience of the manager, particularly those who have prior SME experience. On the other hand, there was no significant relationship between experience and the other variables such as profitability, growth in number of employees, growth in size of enterprise and customer satisfaction.

\subsection{Relationship between Competence and Enterprise Success}

The research considered five (5) different competence indicators namely: technical know-how of the entrepreneurs, their attitude towards work, start-up experience, training experience and industry skills they have acquired over the years to determine if there were significant relationships between these indicators and enterprise success.

\subsubsection{Technical Know-How and Enterprise Success}

The results of the correlation analysis showed a positive relationship between technical know-how of cage fish farmers and the profitability of their enterprises $(r=0.240, p=0.014<$ 0.05); growth in the number of employees $(r=0.231, p=0.018<0.05)$ and customer satisfaction $(r=0.229, p=0.019<0.05)($ Table 2$)$.

Table-2. Relationship between competence and enterprise success

\begin{tabular}{|c|c|c|c|c|}
\hline Variables & $\begin{array}{l}\text { Test } \\
\text { significance }\end{array}$ & $\begin{array}{l}\text { Technical know- } \\
\text { how }\end{array}$ & Attitude & Managerial skills \\
\hline \multirow{3}{*}{ Profitability } & Pearson Correlation & $0.240^{*}$ & 0.041 & $0.258^{*}$ \\
\hline & Sig. (2-tailed) & 0.014 & 0.677 & 0.008 \\
\hline & $\mathrm{N}$ & 105 & 105 & 105 \\
\hline \multirow{3}{*}{$\begin{array}{l}\text { Growth in } \\
\text { Sales }\end{array}$} & Pearson Correlation & 0.128 & $0.242 *$ & 0.085 \\
\hline & Sig. (2-tailed) & 0.193 & 0.013 & 0.391 \\
\hline & $\mathrm{N}$ & 105 & 105 & 105 \\
\hline \multirow{3}{*}{$\begin{array}{l}\text { Growth in } \\
\text { size of } \\
\text { enterprise }\end{array}$} & Pearson Correlation & 0.187 & 0.117 & $0.225^{*}$ \\
\hline & Sig. (2-tailed) & 0.056 & 0.234 & 0.021 \\
\hline & $\mathrm{N}$ & 105 & 105 & 105 \\
\hline \multirow{3}{*}{$\begin{array}{l}\text { Growth in } \\
\text { number of } \\
\text { employees }\end{array}$} & Pearson Correlation & $0.231^{*}$ & 0.050 & 0.147 \\
\hline & Sig. (2-tailed) & 0.018 & 0.613 & 0.136 \\
\hline & $\mathrm{N}$ & 104 & 104 & 104 \\
\hline \multirow{3}{*}{$\begin{array}{l}\text { Customer } \\
\text { Satisfaction }\end{array}$} & Pearson Correlation & $0.229 *$ & 0.012 & $0.300 *$ \\
\hline & Sig. (2-tailed) & 0.019 & 0.902 & 0.002 \\
\hline & $\mathrm{N}$ & 105 & 105 & 105 \\
\hline
\end{tabular}

*. Correlation is significant at the 0.05 level (2-tailed). 
Technical know-how has been regarded as an intangible resource in a firm (Marr and Roos, 2005). The findings imply that as technical know-how of an entrepreneur increases, profit of the business equally increases and the number of employees also increases as well.

In a research, Hormiga et al. (2010) found out that the higher the technical knowledge of the entrepreneur, the greater the possibility of the venture being successful in its initial years of life. This suggests that the higher the technical know-how of entrepreneurs, the higher profits a firm can make, improving customer satisfaction and finally, the higher the growth in sales.

\subsubsection{Respondent's Attitude towards work and Enterprise Success}

Attitude of the entrepreneurs towards work was measured in terms of self-esteem, innovation, risk-taking and personal control as defined by Stimpson et al. (1991). The attitude of entrepreneurs towards work displayed a weak positive relationship with growth in sales $(r=$ $0.242, p=0.013<0.05$ ) (Table 2 ).

The result implies that as the entrepreneurs developed positive attitudes towards their work, there is the likelihood of positive growth in the sales of their fishes, and this confirms the research of Wiklund et al. (2009) who contended that attitude as an entrepreneurial orientation influences success.

\subsubsection{Managerial Skills and Enterprise Success}

Managerial skills were measured according to the skills observed by Kamble (2011) as analytical, time management, interpersonal, communication and conceptual skills. As depicted in Table 2, managerial skills of entrepreneurs showed positive relationships with profitability $(r=$ $0.258, p=0.008<0.05)$, growth in size of enterprise $(r=0.225, p=0.021<0.05)$ and customer satisfaction $(r=0.300, p=0.002<0.05)$.

This suggests that the better the managerial skills of an entrepreneur, the greater the likelihood that the entrepreneur could experience increase in profitability and size of the enterprise. Customers get more satisfaction with the services offered by entrepreneurs who exhibit improved managerial skills.

This situation is consistent with the observations of Samasubbu et al. (2008) who studied customer heterogeneity on customer satisfaction with enterprise system support services.

\subsection{Enterprise Age and Enterprise Success}

There is a debate among authors about whether the age of an enterprise is important as far as success of enterprises is concerned. A significant relationship was found between the age of the cage fish enterprises and growth in sales $(r=0.293, p=0.002<0.05)$ (Table 3).

This meant that the older an enterprise was, the greater the growth it experienced in sales. This finding reinforced the observation that the length of time a business had been in operation was significantly related to business success (Kristiansen et al., 2003; Mazzarol et al., 2011). 
However, there were other findings which suggested that younger firms grew faster than older ones (Ciriaci et al., 2012).

Table-3. Correlation between enterprise age and enterprise success

\begin{tabular}{lll}
\hline Variables & Test of significance & Age of enterprise \\
\hline \multirow{4}{*}{ Profitability } & Pearson Correlation & 0.118 \\
\cline { 2 - 3 } & Sig. (2-tailed) & 0.230 \\
\cline { 2 - 3 } Growth in Sales & $\mathrm{N}$ & 105 \\
\cline { 2 - 3 } & Pearson Correlation & $0.293^{*}$ \\
\cline { 2 - 3 } Growth in size of enterprise & $\mathrm{N}$ & 0.002 \\
\hline \multirow{3}{*}{ Growth in number of Employees } & Pearson Correlation & 0.159 \\
\cline { 2 - 3 } & Sig. (2-tailed) & 0.105 \\
\cline { 2 - 3 } & $\mathrm{N}$ & 105 \\
\cline { 2 - 3 } Customer Satisfaction & Pearson Correlation & 0.008 \\
\cline { 2 - 3 } & Sig. (2-tailed) & 0.933 \\
\hline
\end{tabular}

*. Correlation is significant at the 0.05 level (2-tailed).

\section{CONCLUSIONS}

Among the demographic characteristics studied, age of cage fish farmers had a significant relationship with customer satisfaction indicating that customers got more satisfaction from older farmers. By and large, entrepreneurs use their years of experience to improve upon their interaction with customers.

There was no significant relationship between educational levels of the entrepreneurs and success of the enterprises, implying that the educational attainments had no impact on success of enterprises and this may be due to the fact that the respondents with lower educational status were more than those with higher education. The experience of the cage fish farmer was found to have a significant relationship with growth in sales of the enterprises. Clearly, this implied that longer years at a position would definitely lead to higher sales of fish.

On competence factors of the cage fish farmer, technical know-how had a significant relationship with profitability of their enterprise, growth in the number of employees and customer satisfaction.

Thus, as the technical know-how of the farmer increases there is the likelihood that profitability will increase, number of employees will correspondently increase and therefore customers of the various farmers will be more satisfied with the operations of the farm. The attitude of the farmers towards cage fish farming and their customers recorded a positive significant relationship with growth in sales of the enterprises, implying that better attitudes of a farmer could lead to higher sales of fish. 
According to the findings, job satisfaction of the entrepreneurs showed significant relationships with profitability, growth in the size of enterprise and customer satisfaction. This means that as the entrepreneur is satisfied with the job, he will be able to make more profits as the business grows in size and thus the customers will also derive more satisfaction from such an entrepreneur.

Age as an enterprise characteristic showed a significant relationship with growth in sales, implying that older enterprises over time turn to benefit from higher sales in the cage fish industry. Even though there are other enterprise characteristics, the study was conducted on only age of the enterprise due to time and financial constraints.

\section{RECOMMENDATIONS}

It is hereby recommended that cage fish farmers should seek more assistance from various sources on more technical know-how of cage fish farming to improve the industry.

Additionally, it is relevant for farmers to work on their attitudes towards cage fish farming and customers because a significant relationship was found between attitudes and two variables, while there were other three variables which showed no significant relationship.

Funding: This study received no specific financial support.

Competing Interests: The authors declare that they have no competing interests.

Contributors/Acknowledgement: All authors contributed equally to the conception and design of the study.

\section{REFERENCES}

Ahmad, N.H., C. Wilson and L. Kummerow, 2011. Assessing the dimensionality of business success: The perspectives of Malaysian SME owner-managers. Journal of Asia-Pacific Business, 12(3): 207-224.

Anane-Taabeah, G., 2012. Harnessing the opportunities and overcoming constraints to widespread adoption of cage aquaculture. M.Sc Thesis. Blacksburg, Virginia: Virginia Polytechnic Institute and State University.

Bigsten, A. and M. Gebreeyesus, 2007. The small, the young and the productive: Determinants of manufacturing firm growth in Ethiopia. Economic Development and Cultural Change, 55(4): 813-838.

Ciriaci, D., P.M.P. Castello and P. Voigt, 2012. Does size or age of innovative firms affect their growth persistence? Evidence from a panel of innovative Spanish firms. IPTS Working Papers on Corporate R\&D and Innovation- No. 03/2012.

Creswell, J.W., 2004. Research design: Qualitative, quantitative approaches, and mixed methods approaches. Thousand Oaks, California: SAGE. 
FAO, 2011. National aquaculture sector overview. FAO Fisheries and Aquaculture Department. Available from http://www.fao.org/fishery/countrysector/naso_ghana/en\#tcN900D1 [Accessed 25 May 2012].

FAO, 2012. The state of world fisheries and aquaculture. FAO Fisheries and Aquaculture Department, Rome: 209.

Frimpong, E.A., K.K. Quagrainie, S. Amisah, N.W. Agbo and G. Anane-Taabeah, 2011. Harnessing the opportunities and overcoming the constraints to widespread adoption of cage aquaculture in Ghana. Final Report Submitted to the United States Agency for International Development Aquaculture and Fisheries Collaborative Research Support Program. Corvallis: Oregon.

GHS, 2005. Imagine Ghana free of malnutrition. Available from http://www.ncbi.nlm.nih.gov/pmc/articles/PMC2245943/ [Accessed 25 May 2012].

Hall, G., 2000. Factors associated with the performance of small British firms. A Paper Presented at the 45th International Council of Small Business. Australia: Brisbane.

Hiheglo, P.K., 2008. Aquaculture in Ghana; prospects, challenges, antidotes and future perspectives, MA Thesis. University of Tromsø.

Hormiga, E., R.M. Batista-Canino and A. Sanchez-Medina, 2010. The role of intellectual capital in the success of new ventures. Available from http://www.ub.edu/greie/estils/pdf/the_role_of_intellectual_capital_in_the_succes_of_ new_ventures.pdf [Accessed 24 May 2012].

Islam, M.A., M.A. Khan, A.B.Z. Obaidullah and M.S. Alam, 2011. Effect of entrepreneur and firm characteristics on the business success of small and medium enterprises (SMEs) in Bangladesh. International Journal of Business and Management, 6(3): 289-299.

Kamble, R.R., 2011. Manager skills for organizational performance: An analytical study. Indian Streams Research Journal, 1(1): 23-27.

Kolstad, I. and A. Wiig, 2013. Is it both what you know and who you know? Human capital, social capital and entrepreneurial success. Journal of International Development, 5(25): 626639.

Kristiansen, S., B. Furuholt and F. Wahid, 2003. Internet cafe entrepreneurs: Pioneers in information dissemination in Indonesia. The International Journal of Entrepreneurship and Innovation, 4(4): 251-263.

Lee, S.S. and D. Denslow, 2005. A study on the major problems of U.S. women-owned small businesses. Journal of Small Business Strategy, 15(2): 77-89.

Man, T.W.Y., T. Lau and K.F. Chan, 2002. The competitiveness of small and medium enterprises - a conceptualization with focus on entrepreneurial competences. Journal of Business Venturing, 17(2): 123-142. 
Marr, B. and G. Roos, 2005. A strategy perspective on intellectual capital. In: Marr, B. (Ed.). Perspectives on intellectual capital. Multidisciplinary insights into management, measurement, and reporting. Amsterdam: Elsevier Butterworth-Heinemann. pp: 28-41.

Mazzarol, T., S. Rebound and T. Volery, 2011. The influence of size, age and growth on innovation management in small firms. International Journal Technology Management, 52(1): 98-117

McLeod, S.A., 2008. Likert scale - simply psychology. Available from http://www.simplypsychology.org/likert-scale.html [Accessed 14th May 2014].

McMahon, R.G.P., 2001. Growth and performance of manufacturing SMEs: The influence of financial management characteristics. International Small Business Journal, 19(3): 10-28.

McPherson, M., 1996. Growth of micro and small enterprises in Southern Africa. Journal of Development Economics, 48(2): $253-277$.

Michalos, A.C., H. Creech, N. Swayze, P.M. Kahlke, C. Buckler and K. Rempel, 2011. Measuring knowledge, attitudes and behaviours concerning sustainable development among tenth grade students in Manitoba. Social Indicators Research, 106(2): 213-238.

MOFA, 2012. Agriculture in Ghana: Facts and figures, SRID. MOFA, Accra.

MOFA, 2013. Fish production, imports, exports and consumption. Available from http://mofa.gov.gh/site/?page_id=2862 [Accessed 28th June 2014].

Ofori, J.K., 2000. Status and trends in integrated agriculture-aquaculture in Ghana. In E.K. Abban, C.M.V. Casal, T.M. Falk and R.S.V. Pullin (eds.). Biodiversity and sustainable use of fish in the coastal zone. International Workshop, Accra, Ghana. ICLARM Conf. Proceedings, 63.

Reynolds, P.D., M. Hay, W.D. Bygrave, S.M. Camp and E. Autio, 2000. Global entrepreneurship monitor 2000 executive report: Babson College. Kauffman Center for Entrepreneurial Leadership, and London Business School.

Rutherford, M.W. and S.L. Oswald, 2000. Antecedents of small business performance. New England Journal of Entrepreneurship, 3(2): 21-33.

Samasubbu, N., S. Mithas and M.S. Krishnan, 2008. High tech, high touch: The effect of employee skills and customer heterogeneity on customer satisfaction with enterprise system support services. Decision Support Systems, 44(2): 509-523.

Simpson, G., 2012. Opportunities for small scale suppliers within the tilapia value chain in Ghana: A case study of fish farming in Achavanya. M.Phil Thesis. International Institute of Social Studies. The Hague, Netherlands.

Simpson, M., N. Tuck and S. Bellamy, 2004. Small business success factors: The role of education and training. Education and Training, 46(89): 481-491.

Sinha, T.N., 1996. Human factors in entrepreneurship effectiveness. The Journal of Entrepreneurship, 5(1): 23-39. 
Stimpson, D.V., P.B.J.C. Robinson and H.K. Hunt, 1991. An attitude approach to the prediction of entrepreneurship. Entrepreneurship Theory and Practice, 13(4): 13- 31.

Thapa, A., A. Thulaseedharan, A. Goswami and L.P. Joshi, 2008. Determinants of street entrepreneurial success. The Journal of Nepalese Business Studies, 5(1): 85-92.

Unger, J., A. Rauch, M. Frese and N. Rosenbusch, 2011. Human capital and entrepreneurial success: A meta analytical review. Journal of Business Venturing, 26(3): 341-358.

Verhees, F.J.H.M. and M.T.G. Meulenberg, 2004. Market orientation, innovativeness, product innovation, and performance in small firms. Journal of Small Business Management, 42(2): 134-154.

Wiklund, J., H. Patzelt and A. Shepherd, 2009. Building an integrative model of small business growth. Small Business Economics, 32(4): 351-374.

Woldie, A., P. Leighton and A. Adesua, 2008. Factors influencing small and medium enterprises (SMEs): An exploratory study of owner/manager and firm characteristics. Banks and Bank Systems, 3(3): 1-9. 